\title{
Cinema and Conflict in Postcolonial Mozambique: Archival Images as Illustration and Evidence in Estas São as Armas (1978)
}

\section{Robert Stock}

\section{INTRODUCTION}

When the film Estas são as armas came out in 1978, just three years had passed since Mozambique's independence. Within this short period of time, the young socialist country governed by Frente da Libertação de Mocambique (Frelimo) had founded and established the Instituto Nacional de Cinema (INC). During the next two decades the INC produced a series of feature films and documentaries as well as the well-known newsreel Kuxa Kanema (Taylor 1983, p. 30; Loftus 2012) that became one of the important centers for film production in sub-Saharan Africa in the 1970s and 1980s (Andrade-Watkins 1995, p. 139). The INC also became a gathering place for filmmakers, technicians, cameramen, and other enthusiasts from both the Americas and Europe. Together with Mozambican supporters, this institution trained young people interested in film production, creating a legacy that continues today (Roof 2004; Pasley 2009). Estas são as armas embodies this transnational connection as its director, Brazilian Murilo Salles, collaborated with the writer and politician Luís Bernardo Honwana on the production of the first full-length documentary made by the INC (Filme Cultura 1988; Hamilton 1975, pp. 212-20). 
However, following the end of the prolonged decolonization war and subsequent end of Portuguese rule in $1975,{ }^{1}$ other conflicts emerged due to the political situation in sub-Saharan Africa. ${ }^{2}$ There, an independent Mozambique 'was seen with alarm by white-minority regimes in Rhodesia and South Africa' (Finnegan 1992, p. 31). The Mozambican government took a clear stand against Ian Smith's regime in neighboring Rhodesia by closing its borders and cutting all connections to Rhodesia in $1976,{ }^{3}$ causing serious economic problems for the state. Soon afterwards, Rhodesian aggression started and troops began to attack civilian objectives on Mozambican territory (Allen 1977). This began one of the most violent wars in South African history: a complicated and prolonged conflict that only ended with the General Peace Agreement in 1992.4

Estas são as armas articulates the above outlined tension in Mozambique at the end of the 1970s. Entirely produced in Mozambique, ${ }^{5}$ the film addresses the Rhodesian attacks on Mozambique after 1976. It relates the loss of human life and destruction of civilian infrastructure such as bridges, hospitals, and schools caused by these attacks alongside the colonial history and struggle for independence. The film argues for legitimating Frelimo and supports the idea of 'liberation' and independence

${ }^{1}$ The wars for independence in the Portuguese African colonies took place from 1961 to 1974. On April 25, 1974, the Carnation Revolution abolished the authoritarian regime and the African territories like Angola, Mozambique, Guinea Bissau, and others subsequently gained independence (Mateus 1999; Pinto 2001).

${ }^{2}$ The year 1975 marks an important shift in the history of southern Africa, the winning/ gaining of independence by Mozambique and Angola. [...] With independence, they proclaimed the first state of people's democracy in the southern part of the continent' (José and Vieira 1992, p. 16)

${ }^{3}$ After the independence, the new Mozambican government decided to accept a United Nations instruction relating to sanctions to Rhodesia and closed the railway connections. This deprived the young country of important revenue needed to rebuild the nation (Birmingham 1995, p. 57).

${ }^{4}$ Due to economic and political reasons, Rhodesia and its army started to launch attacks inside Mozambique in 1976. Attacks by Renamo started in 1977. The violent war only ended in 1992, claiming about one million lives and leaving approximately four million displaced (Seibert 2003, p. 254; see also Dinerman 2006).

${ }^{5}$ The closing credits of the film hence state: 'Agradecemos a todos que apoiaram e tornaram a produção deste filme possível. Este filme foi totalmente produzido em Moçambique. Laboratórios I.N.C.' [We thank all who have supported us and made the production of this film possible. This film was entirely produced in Mozambique.] (my translation). The participation of Murilo Salles and Luís Bernardo Honwana was addressed later (Filme Cultura 1988 , pp. 7-8; Convents 2011, p. 443) while accusing Rhodesia of collaborating with imperial Portugal in its war against the Mozambican nationalists and the use of excessive military violence against targets in Mozambique after 1976 (Convents 2011, p. 443).

In order to develop its rhetoric, the film draws on a variety of audio-visual sources. This includes films about Frelimo and the struggle for independence from 1964 to 1974 . Films like these were produced by the independence movements in close cooperation with individual filmmakers like Margaret Dickinson, Robert van Lierop, and Lennart Malmer (Dickinson 2011 Crowdus and Gupta; Diawara 1992, p. 90). Being politically engaged, their films about the 'liberated zones' in northern Mozambique were shown in Europe and the United States to raise questions about the colonial policies of Portugal in Africa (Diawara 1992, p. 89). Estas são as armas also draws upon colonial newsreels (Piçarra 2011, pp. 115-123; de Matos-Cruz 1999) and films produced by the state television program Radiotelevisão Portuguesa and the Cinematographic Services of the Army (Cádima 1996; Mendonça 1993; Convents 2011, p. 329). The colonial footage included was originally produced by production companies working in Lourenço Marques and was taken into the INC's archives following the political change in 1975; the extensive extracts Estas são as armas uses to make its arguments plausible stem from official archives. ${ }^{6}$ The film therefore takes moving images made in a context where films and their production were part of the 'cultural politics of colonial rule' (Cooper and Stoler 1989, p. 619) that were 'used to justify the imposition of [...] colonial authority' (Bloom 2008, p. vii) and reinvests them with new meaning. Like many other filmic productions, Estas são as armas therefore exercises and articulates a specific postcolonial memory politics (Ukadike 2004; Thackway 2003, pp. 93-1 19). In addition to the material predating 1975 , extracts from the documentary report $O$ massacre de Nyazônia (1977, Fernando Silva) are also included. This film was intended to 'fornecer um equilíbrio às reportagens na imprensa ocidental sobre Nyazônia que apresentaram quase sempre o ponto de vista do governo na Rodésia' (Convents 2011, p. 470). ${ }^{7}$

${ }^{6}$ These audio-visual productions emerged in a context where the public sphere was controlled by an authoritarian regime with strong censorship ( $V_{2 z}$ 1997). As Frelimo invited foreign filmmakers to make films about the liberated areas, these films often reproduced Frelimo's political perspectives. Therefore, the independence movement exercised a certain control over its cinematographic representation (Diawara 1992, p. 89).

7 The film was intended to offer a balance to Western press reports on Nyazonia, since they have always been presented from the viewpoint of the Rhodesian government (my translation).

One of the central points of reference in the film is the massacre of Nyazônia: an attack on a refugee camp by Rhodesian military forces in which hundreds of people died (Finnegan 1992, p. 31). 
Since the 1970s moving images taken from the colonial period or the struggle for independence have continued to be used in filmic reconstructions of Mozambican history. Examples include Joaquim Furtado's television series A Guerra. Colonial. Do Ultramar. De Libertação (20072010), which discusses the decolonization of Angola, Guinea Bissau, and Mozambique by drawing on archival images and interviews with veterans, and Natal 71 (1999) by Margarida Cardoso, which develops a particularly aesthetic way of negotiating moving images from Portuguese archives. Through the employment of audio-visual testimony and other strategies, these films address the colonial past differently (but sometimes no less politically) than the films of the postrevolutionary 1970 s, such as Deus Pátria Autoridade (1976) or Estas são as armas (1978), which are mainly informed by a political and anti-colonial, anti-imperialist discourse. ${ }^{8}$

As space restrictions limit the comparative analysis of these and other films, this essay will focus on the Mozambican production Estas são as armas (1978).9 In doing so, I provide much needed response to, and extension, of recent work on Mozambican and Lusophone cinema (Diawara 1992, pp. 88-103; Andrade-Watkins 1995; Eshun and Gray 2011; Arenas 2011; Ferreira 2012; Meleiro 2012). Among the various studies on sub-Saharan cinema, film production, and individuals, such as Jean Luc Godard or Ruy Guerra, and in addition to the detailed overview of the history of cinema in Mozambique by Guido Convents, few studies analyze specific films. ${ }^{10}$ More work on

${ }^{8}$ Another example is the film 25 (1976, Celso Lucas and José Celso Correa), which advances a cinematographic experiment and proposes a revolution in both society and film culture (Monteiro 2011)

For an overview on films about African history see Cham (2004), Bickford-Smith and Mendelsohn (2007). For general developments of Lusophone and African cinema consult Andrade-Watkins (1995), Armes (2006), Convents (2011).

${ }^{2} \mathrm{I}$ am pursuing the analysis of this and other productions within a $\mathrm{PhD}$ project at the International Graduate Centre for the Study of Culture (University of Giessen). However, my dissertation project aims at studying documentary films from both Mozambique and Portugal, namely productions after 1975 that negotiate the colonial past. The aim of the research consists of examining the various uses and functions of archival images and testimonies in documentaries discussing the decolonization of the Portuguese colonies in Africa.

${ }^{10}$ See for example the dissertation of Raquel Schefer (Paris; 2011) who is working on the film Mueda. Memória e Massacre (1979) by Brazilian-Mozambican filmmaker Ruy Guerra or the work of Ute Fendler (Bayreuth), who also participates in the annual Dockanema Documentary Festival, who is examining films by Licinio de Azevedo. this subject, and specifically the relationship between history and film, is needed to provide further insight into the cinematic representation of African decolonization. A close reading of these films can shed light on audio-visual negotiations of the colonial past and thereby provide insights into the cultural dimensions of decolonization.

\section{Archival Images in Historical Documentaries: VOICE VERSUS IMAGE}

Having provided some background on cinematographic production and the situation in Mozambique, I now discuss some ideas on archival images in documentary films to enable a better understanding of the strategies used in films like Estas são as armas, where archival images are reframed through techniques such as the voice-over comment. Archival images, as Jorio et al. (2011) note, are 'a discursive element based on the promise of the satisfaction of remembrance.' From this position, they argue that 'an archival image is to be understood as an element whose original context is both spatially and chronologically distinct from that of the moment when it is used again.' In historical documentaries, the voice-over is commonly used to order the various materials used to present a certain event. Often, 'a narrator [...] speaks while we see recent footage of historical sites intercut with older footage, often from newsreels, along with photos, artifacts, paintings' (Rosenstone 2001, p. 50). But while voice and images are juxtaposed they are also interrelated and form a hierarchical order, especially when included in a political documentary. To explain this structure, one could follow Bill Nichols, who argues that (archival) images in documentary films are mostly used to illustrate a certain 'argument about the world.' A good example of such a configuration is documentaries in the expository mode as they rely 'heavily on an informing logic carried by the spoken word in a reversal of the traditional emphasis in film, images serve a supporting role' (Nichols 2010 , pp. 167-168). In many cases, this point might be plausible when looking at more official productions.

However, at the same time, it seems a rather simplifying explanatory model because the structure of these films is more complex, as Judith Keilbach (2010) convincingly demonstrates in her analysis of German documentaries on the Nazi period (2010, p. 99). Besides the illustrative function of images where footage serves merely as 
a visible addition for what is said without explicit reference to the people or situation shown in the images, ${ }^{11}$ documentaries also present certain images. In the latter case, viewers are requested to look at the image and direct their attention to specific elements in the picture. The image is ascribed an 'argumentatively and visually intrinsic value." ${ }^{12}$ There is therefore a particular relationship between image and the spoken word, a complex interaction that goes beyond the binary scheme of dominant voice-over and subordinated footage that has to be analyzed case by case. Furthermore, this means of combining images with sounds or voices can also initiate processes of resignification. As Sergei Eisenstein puts it 'montage is not an idea composed of successive shots stuck together but an idea that DERIVES from the collision between two shots that are independent of one another' (1998, p. 95)

That is, the editing of footage from the colonial period with images from a postcolonial reality enables a renegotiation and creation of a new context of meaning, which is furthered and mediated by strategies like 'illustration,' 'presentation,' and the like.

\section{AN ANALYSIS OF ESTAS SÃO AS ARMAS (1978)}

The following brief analysis of Estas são as armas highlights some of the particular techniques used. I begin with the premise that the structure and production of documentary films primarily addressing political and historical topics cannot be reduced to a model in which the voice-over commentary is conceived as the unchallenged ruler over the visual. As will be demonstrated, additional strategies can foreground the visual features of the colonial footage and render these images as evidentiary cues that in turn constitute important elements of the film's argument.

11 'When footage is used illustratively, it is subordinate to the voice-over commentary without explicitly explaining the filmed situation or people. [...] As a consequence, the viewer's attention is not drawn to the images that seem to be immediately evident, but rather concentrates on the dominant voice-over commentary.' (Keilbach 2010, p. 100)

12 'The presentation of historical footage concentrates the viewer's attention on the visual by the use of different techniques. [...] The presentation is thus an invitation to look at and it therefore confers an argumentatively and visually intrinsic value to the image.' (Keilbach 2010, p. 103)

\section{Images as Illustration}

Estas são as armas aims to cinematographically affirm the position of an independent Mozambique in Sub-Saharan Africa and was intended as a contribution to a complex nation building process within a geopolitical setting shaped by white minority regimes. Therefore, when analyzing the film's perspective and argument, one has also to consider it as a form of identity politics reliant on the construction of an 'own' national history (cf. Wolf 1982). This includes both colonialism and the struggle for independence. As such, this filmic articulation is closely related to what Eduardo Mondlane writes about nationalism in Mozambique:

Como todo o nacionalismo africano, o de Moçambique nasceu da experiência do colonialismo europeu. [...] Em Moçambique foi a dominação colo. nial que deu origem à comunidade territorial e criou as bases para uma coerência psicológica, fundada na experiência da discriminação, exploração, trabalho forçado e outros aspectos da dominação colonial. ${ }^{13}$ (Mondlane quoted in Sousa 2008 , p. 149)

Against this backdrop, the first step of this analysis consists of scrutinizing the voice-over as a means to provide information about the authorship and the arguments advanced within the film. I therefore begin with an analysis of archival images as an illustrative tool to enhance verbal rhetoric through visual information.

One scene at the beginning of the film illustrates this technique well. The opening credits are followed by footage of the equestrian statue of Mouzinho de Albuquerque situated in the center of Lourenço Marques in front of the city hall. ${ }^{14}$ The Estado Novo, with its discourse on Portugal's mission of colonization and evangelization, emphasized the significance of figures like Mouzinho, a leading military official in occupation cam-

${ }^{13}$ As with all African nationalisms, Mozambican nationalism was born out of the experience of European colonialism. In Mozambique the colonial domination originated the territorial community and created the basis for a psychological coherence, founded on the experience of discrimination, exploitation, forced labor and other aspects of the colonial domination (my translation).

${ }^{14}$ The monument was removed in 1975 (Morton 2010). Nowadays, the statue of Mouzinho and the reliefs showing the imprisonment of Gungunhane can be visited in the inner courtyard of the Forte de Nossu Senhora da Conceicão in Maputo. The films 25 (1976, Celso Lucas and José Celso Correa) and Le double vie de Dona Ermelinda (1995, Aldo Lee) use the footage of the removal in distinct ways. 
paigns around 1900 (Wheeler 1980, pp. 314-117; Fernandes 2010). While the moving images of Mouzinho's statue made before 1974 were used as part of an official discourse, which foregrounded the presence of the Portuguese in East Africa as well as its merits in developing the colony and building European like urban centers, in the context of Estas são as armas the footage provides a visual background for a counterdiscourse accusing the colonial power(s) of aggression. The voice-over frames them:

Moçambique foi dominado pelo colonialismo português durante 500 anos. Durante 500 anos, e, principalmente depois da chamada Guerra de Ocupação, nós aprendemos que o verdadeiro rosto do colonialismo é a agressão. Os exércitos coloniais são exércitos de agressão. O colonialismo, ele próprio, é uma agressão permanente. Uma agressão que tem por fim manter a dominação para realizar a exploração. ${ }^{15}$

The hierarchy of the auditory and visual elements is evident. The images, which stress the monumentality of Mouzinho and its memorialization through the use of low angle shots that foster 'looking up' to the military leader, serve here to illustrate the violent dimension of the colonization process in Mozambique as the imprisonment of Gungunhane by Mouzinho and its troops in 1895 occupies a central place (Alexandre 2000 ; see also Garcia 2008). The visual material is subordinate to the commentary without explicit reference or explanation for the visuals. Lacking identification or specification, the footage provides a nonproblematic visualization of the text. Consequently, viewers are likely to focus on the dominant voice-over rather than the seemingly self-evident visual (Keilbach 2010 , p. 100). Regarding the '500 years' mentioned in the voice-over, it is quite obvious that such a statement simplifies the complexity of historical reality (Newitt 1995, pp. 517-614). Simultaneously, when seen in its socio-political context, the affirmation reveals its close relation with official Frelimo discourse on the colonial past (Frelimo 1971 , pp. 34, 78; Muiuane 2006, pp. 112-113, 462-463, 474-475), where a rather dichotomous view in which there was little or no dynamic

${ }^{15}$ Mozambique has been dominated by Portuguese colonialism for 500 years. For 500 15 true face is aggression. Colonial armies are aggression armies. Colonialism itself is a permanent aggression. An aggression that has as its goal to maintain domination in order to carry on exploiting (my translation). beyond the scheme of oppression, collaboration, and resistance predominated (Bragança and Depelchin 1989; Cooper 1994, p. 1517).

This use of colonial footage to illustrate the argument presented by the voice-over can also be found in another scene where images of poor cotton workers or wealthy settlers and 'colonialists' are subordinated by a 'Mozambican' voice. A particular characteristic that somehow distinguishes this film from others that solely employ 'the cultivation of the professionally trained, richly toned male voice of commentary' (Nichols 2010 , p. 105), is the introduction of an equally important female voice. In several scenes, which address the economic exploitation in cotton growing and other topics, this voice furthers the construction of a (female) national identity and thereby addresses Frelimo discourse on the idealized role of women during the struggle for independence and during the reconstruction of the country after 1975 (Arnfred 2004, pp. 113-119).

\section{Archival Images as Evidence}

While the film mainly relies on a scheme where a dominant voice-over is illustrated by archival images, some scenes apply other strategies and foreground particular images in order to convey a certain argument. Specifically, images are presented so as to direct the viewer's attention towards the visual (Keilbach 2010, p. 103).

One such moment occurs in the sequence on the presence of Rhodesian troops in Mozambique and their participation in the war of independence. Besides being an important neighbor and partner to colonial Mozambique and Portugal, Rhodesia provided military support for the construction of the Cahora Bassa dam. As such, a new (military) constellation emerged in Northern Mozambique where Rhodesia and South Africa provided troops to protect the construction site and convoys of materials (Barroso 2009; Huffman 1992, p. 17; Henriksen 1983, pp. 29, 34).

In the film, a contrast is set between a guiding male voice-over, which presents the broader context surrounding Cahora Bassa, including illustrative footage, and a female voice, which provides a detailed description of a photograph. Beginning with a close-up where only the legs of some soldiers are recognizable, viewers might be puzzled by the initial framing until the voice-over informs the viewer that: 'Esses de calçoes, são rodesianos. ${ }^{16}$ The item of interest in this picture turns out to be the

${ }^{16}$ 'Those wearing shorts are Rhodesians (my translation). 
uniform, whereby some of the soldiers can be identified as elements of the Rhodesian armed forces. Then, when the film subsequently cuts to show the entire photograph, it first appears that the photograph was probably taken by one of the soldiers as the features are those of a snapshot rather than an organized group picture. However, the female voice-over continues to recontextualize the photograph: 'Esta foi uma das muitas operações conjuntas que realizaram com o exército colonial português.'17

Rather than dominate the image, the voice-over seems to provide a "caption" by directing the viewer's attention (Arthur 1997, p. 4; Zryd 2003, p. 48). The instructions to observe details located in the image further the isolation of individual elements, specifically the soldier's uniforms, accentuating the picture's literal dimension (Keilbach 2010, p. 103). ${ }^{18}$ By doing so, the snapshot is transformed into a kind of visual proof that functions as an evidence-producing element in the film's argument (see Campany 2008, pp. 115-118). Hence, the combination of voice-over and photograph contribute to reinforcing the delegitimization of Rhodesian politics that have aimed to weaken and destabilize Frelimo's efforts since the 1960 s. $^{19}$

\section{Constructing Victory Through Sound and Image}

The film's political perspectives are clear in its presentation of the Mozambican Liberation Front. Throughout the film, Frelimo is characterized as a unified force that successfully combats the colonial power. Although the film sketches a rather simplified and biased version of the decolonization war in Mozambique, some of the sequences are worth analysing for the application of filmic strategies and persuasive techniques using archival images.

For instance, one of the sequences in Estas são as armas describes the armed struggle of Frelimo against Portuguese rule in Mozambique. Combat is reconstructed through the juxtaposition of footage from Frelimo films

${ }^{17}$ This was one of the many military operations they undertook with the Portuguese colonial army (my translation).

${ }^{18}$ 'The instruction to see something in the image highlights its literal sense and emphasizes the reification of the image, accompanied by a simultaneous isolation of its single elements. (Keilbach 2010, p. 103)

${ }^{19}$ When the film goes on to explain the violent tactics used by Rhodesian troops in order to intimidate civilian populations, it promptly returns to the expository mode where images again merely serve as a simple means of illustration. with other archival images produced by the Portuguese armed forces. The scene showing military action is followed by an extract of the television program Conversas em Familia where Marcello Caetano denies the existence of any armed conflict in the overseas territories (cf. Ribeiro 2004 , p. 26; Cádima 2010). His statement, shown without interfering comment, is subsequently contradicted: Footage showing Portuguese soldiers in African territories shows the problems in Mozambique. Additionally, images of injured Portuguese soldiers demonstrate that this problem was far from being resolved. However, these images serve only as a backdrop for the female voice-over:

Marcelo Caetano diz que não há guerra colonial. Ele queria que os soldados portugueses viessem a Moçambique matar secretamente e também morrer secretamente. Caetano não sabia que não se pode parar o vento com as mãos. Não se pode derrotar um povo determinado que pega em armas para se libertar de dominação. ${ }^{20}$

To then show that the struggle for independence was successful, an interesting montage of various shots taken from Caetano's televised address combines different footage of Portuguese military vehicles. The first scene, probably taken from a production of the Portuguese Armed Forces (Mendonça 1993), shows a military parade shot in Lourenço Marques where formations of Portuguese soldiers march past followed by military artillery and vehicles. The footage is intercut with a shot showing soldiers on a vehicle moving through rough terrain followed by images of a huge scrap yard with innumerable wrecked and rusty military vehicles. While the parade footage remains intact, including its original military march soundtrack, the impressions of the scrap yard are accompanied by complete silence. This confrontation between a kinetic and audible Portuguese military machine and a motionless and silent vehicle cemetery is repeated three times before being succeeded by a brief visual allusion to Mozambique achieving independence on June 25 1975. The deliberate silencing of the soundtrack creates a vacuum that compels the viewer to realize the implications of the scrap yard images: immobile and rusty scrap metal. In alluding to the subsequent destruction of their equipment,

${ }^{20}$ Marcelo Caetano claims there is no colonial war. He warned that Portuguese soldiers came to Mozambique to kill in secret and also to die in secret. Caetano was aware that you cannot stop the wind with your bare hands. You cannot defeat a determined people who take up arms in order to free themselves of domination. (my translation) 
this technique renders the footage evidence of the futility of Portuguese efforts to hold Mozambique. In particular, the sound editing supports the creation of a short visual narrative implying that Frelimo's (successful) military actions effectively led to Mozambique's independence. The images of the scrap yard thereby symbolize the defeated Portuguese forces and suggestively hint at Frelimo's victory, a rather unilateral perspective that also downplays the difficulties Frelimo encountered during the course of the war (Newitt 1995, pp. 523-527).

\section{CONCLUSION}

The above analysis has shown how the film makes use of various strategies to recontextualize archival images from a postcolonial and socialist perspective. Specifically, the images illustrate and thereby support information given by the voice-over; they illustrate particular items or are embedded in montages where sound, silence, and the visual communicate through contrasting juxtaposition. However, a specific political perspective is ever present throughout the film. Through the use of voice-over commentary and archival images, a historical master narrative is produced that presents colonial oppression, collaboration, resistance, liberation, and the subsequent attempt to survive a hostile geopolitical situation. But while Estas são as armas gives voice to the discourse of a national elite engaged in the construction of the new country, it denies such a voice to the common people. For instance, although Mondlane and his collaborators collected the testimony of rural cotton workers and others (Mondlane 1983, pp. 44-49, 85-89), the film makes no use of this material but substitutes the colonial voice-over with another dominant discourse when showing newsreels about cotton harvest, thereby silencing the subalterns. Furthermore, in the context of an idealized national history written by Frelimo, internal issues like the handling of political opponents, former political prisoners, or the challenges the movement faced when trying to build the 'homem novo' have no place (Igreja 2010). Still, this is not surprising when taking into account that Estas são as armas is closely linked to a period in which a certain type of cinema, a 'liberation cinema' (Andrade-Watkins 1995, p. 135) prevailed.

Following socio-political changes, cinematographic production was restructured and the free market production of the 1980s was followed by private sector production at the beginning of the 1990s (Convents
2011). While a large number of the films produced in Mozambique addresses social and health issues (i.e., AIDS) a considerable number also engage with contemporary reality or the country's history. One of the most important directors in this respect is Licínio Azevedo. Along with the production company Ebano Multimedia, Azevedo directed Ferro em brasa (2006) about the photographer Ricardo Rangel and Hóspedes da Noite (2007) about daily life in Grande Hotel in Beira. Both search to articulate the legacy of the colonial past that continues to have an impact on today's Mozambican society (Arenas 2011). ${ }^{21}$ At a time when the INC is slowly recuperating from its decay, and near end, during the $1990 \mathrm{~s}$ (Costa 2008), which is compellingly portrayed in Margarida Cardoso's Kuxa Kanema. O Nascimento do Cinema (2003), Mozambican and other filmmakers (e.g., Lotte Stoops or Ike Bertels) are exploring approaches that reconstruct the past and enable discussion of the present. Happily, Mozambican film finds great support in the Maputo documentary festival Dockanema that provides a platform for an emerging multifaceted film culture. However, as far as recent commemorative initiatives are concerned, one must remember that government officials celebrated ' $O$ ano de Samora Machel' [the year of Samora Machel] in 2011 and Frelimo commemorated its 50th anniversary in 2012. In addition, Muiuane's book on the history of the Liberation Front is still in use and statues of Samora Machel have been erected in many cities in the past two years. This was also the case in Maputo, where a huge monument of Samora Machel now stands in front of the city hall, occupying the void left by the statue of Mouzinho de Albuquerque. Against the backdrop of an officially shaped (urban) memory scape relying on the idealization of former political leaders and scattered filmic interventions, one is reminded of the practice of 'forgetting from above and memory from below' pointed out by Pitcher (2006). The question remains where and when it will be possible for official and experimental cinematographic attempts to negotiate Mozambique's past to meet.

Acknowledgment I gratefully acknowledge the support of the Gerda Henkel Stiftung who provided funding for my research trips to Lisbon and Maputo in 2011.

${ }^{21}$ In addition, with his new film Virgem Margarida (2012), Azevedo also engages in the discussion of problematic themes like the re-education camps in socialist Mozambique, an issue not likely to be addressed by Frelimo. 


\section{REFERENCES}

Alexandre, V. (2000). Situações Coloniais: II-O Ponto de Viragem; As Campanhas de Ocupação (1890-1930). In F. Bethencourt, K. Chaudhuri, \& V. Alexandre (Eds.), Do Brasil para África. (1808-1930) História da expansão portuguesa (Vol. 4, pp. 182-208). Lisbon: Temas e Debates.

Allen, C. (1977). Exclusive report from Mozambique: A high price on development. Executive Intelligence Review, 4(44), 1-4.

Andrade-Watkins, C. (1995). Portuguese African cinema: Historical and contemporary perspectives. 1969 to 1993. Research in African Literatures, 26(3), $134-150$.

Arenas, F. (2011). Lusophone Africa: Beyond independence. Minneapolis: University of Minnesota Press.

Armes, R. (2006). African filmmaking: North and South of the Sabara.

Arnfred, S. (2004). Concepts of gender in colonial and post-colonial discourses: The case of Mozambique. In Codesria (Ed.), Gender activism and studies in Africa (pp. 108-128). Dakar: Codesria.

Arthur, P. (1997). On the virtues and limitations of collage. Documentary Box, 11 , 1-7.

Barroso, L. M. (2009). Salazar e Ian Smith: O Apoio de Portugal à Rodésia (19641968). Lisbon: Ministério dos Negócios Estrangeiros MNE.

Bickford-Smith, V., \& Mendelsohn, R. (Eds.). (2007). Black and white in colour: African history on screen. Oxford: Currey.

Birmingham, D. (1995). The decolonization of Africa. Athens: Ohio University Press.

Bloom, P. (2008). French colonial documentary: Mythologies of humanitarianism. Minneapolis: University of Minnesota Press.

Braganç, A., \& Depelchin, J. (1989). Da Idealização da FRELIMO a Compreensão da História de Mozambique. Estudos Mocambicanos, 5/6, 29-52.

Cádima, F. R. (1996). Salazar, Caetano e a Televisão Portuguesa. Lisbon: Presença.

Cádima, F. R. (2010). Imagens e Representaçōes da Ditadura Portuguesa na Televisão (1957-1974). Logos, $17(1), 56-69$.

Campany, D. (2008). Photography and cinema. London: Reaktion Books.

Cham, M. B. (2004). Film and history in Africa: A critical survey of current trends and tendencies. In F. Pfaff (Ed.), Focus on African films (pp. 48-68) Bloomington: Indiana University Press.

Convents, G. (2011). Os Moçambicanos Perante o Cinema e o Audiodisual: Uma História Politica-cultural do Mofambique Colonial até à Repriblica do Moçambique (1896-2010). Maputo: CP-Conteúdos e Publicações.

Cooper, F. (1994). Conflict and connection: Rethinking colonial African history. The American Historical Review, $99(5), 1516-1545$.

Cooper, F., \& Stoler, A. L. (1989). Introduction: Tensions of empire: Colonial control and visions of rule. American Ethnologist, 16(4),609-621.
Costa, J. M. (2008). Mission in Maputo: Saving the film collection at INAC. Journal of Film Preservation, 76, 25-28.

de Jorio, I. et al. (2011). Defining/Becoming an archival image-Définir/Devenir une image d'archives: Call for Papers. Retrieved Juni 02, 2014, from http:// hsozkult.geschichte,hu-berlin.de/termine/id=17979\&vi.

de Matos-Cruz, J. (1999). Cinema Luso-Moçambicano. Revista Camões, 2(6), $38-45$.

Diawara, M. (1992). African Cinema. Politics \& Culture. Bloomington: Indiana University Press.

Dickinson, M. (2011). Flashbacks from a continuing struggle. Third Text, 25(1), 129-134.

Dinerman, A. (2006). Revolution, counter-revolution and repisionism in postcolonial Africa: The case of Mozambique, 1975-1994. London; New York: Routledge.

Dockanema (Ed.). (2010). Festival do Filme Documentário: Catálogo. Maputo: Ebano Multimedia.

Eisenstein, S. (1998). The dramaturgy of film form (The dialectical approach to film form) (1929). In $\mathrm{R}$. Taylor (Ed.), The Eisenstein reader (pp. 93-110). London: BFI.

Eshun, K., \& Gray, R. (2011). The militant image: A Ciné-geography. Third Text, $25(1), 1-12$.

Fernandes, P. J. (2010). Mouzinbo de Alburquerque: Um soldado ao serviço do Império, Biografia. Lisbon: A Esfera dos Livros.

Ferreira, C. O. (2012). Identity and difference: Postcoloniality and transnationality in lusophone films. Münster: Lit.

Cultura, F. (1988). Eu tinha que fazer um Filme sobre a Geração 68': Entrevista com Murilo Salles'. Film Cultura, 48, 6-13.

Finnegan, W. (1992). A complicated war: The harrowing of Mozambique. Berkeley: University of California Press.

Frelimo (Ed.). (1971). História de Moçambique. Porto: Edições Afrontamento.

Garcia, J. (2008). O Mito de Gungunhana na Ideologia Nacionalista de Moçambique. In L. R Torgal, F. Tavares Pimenta, \& I. Soares Sousa (Eds.) Comunidades Imaginadas: Nação e Nacionalismos em África (pp. 131-148). Coimbra: Imprensa da Universidade de Coimbra.

Gray, R. (2011). Cinema on the cultural front: Film-making and the Mozambican Revolution. Third Text, 25(1), 139-160.

Hamilton, R. G. (1975). Voices from an Empire: A bistory of Afro-Portuguese literature. Minneapolis: University of Minnesota Press.

Henriksen, T. H. (1983). Revolution and counterrevolution: Mozambique's war of independence; 1964-1974. Westport: Greenwood Press.

Huffman, R. T. (1992). Colonialism, socialism and destabilization in Mozambique. Africa Today, $39(1 / 2), 9-27$ 
Igreja, V. (2010). Frelimo's political ruling through violence and memory in postcolonial Mozambique. Journal of Southern African Studies, 36(4), 781-799.

José, A. \& Vieira, S. (1992). 1974-1975. The great turning point. Consequences of Angolan and Mozambican independence. In S. Vieira, W. G. Martin, \& I. Wallerstein (Eds.), How fast the wind? Southern Africa, 1975-2000 (pp. 16-30). Trenton: Africa World Press.

Keilbach, J. (2010). Geschichtsbilder und Zeitzewgen: Zur Darstellung des Nationalsozialismus im bundesdeutschen Fernseben. Münster: Lit.

Loftus, M. (2012). Kuxa Kanema: The rise and fall of an experimental documentary series in Mozambique. Journal of A frican Cinemas, 3(2), 161-171. Print.

Mateus, D. C. (1999). A Luta pela Independência: A Formação das Elites Fundadoras da FRELIMO, MPLA e PAIGC. Mem Martins: Inquérito.

Meleiro, A. (2012). Luso-African cinema: Nation and cinema. Editorial. Journal of African Cinemas, 3(2), 135-138. Print.

Mendonça, E. (1993). O Cinema Produzido pelo Serviço Cartográfico do Exército nas Campanhas de Africa, 1961-1974. Lisbon: Universidade Católica Portuguesa.

Mondlane, E. (1983). The struggle for Mozambique. London: Zed Press [1969].

Monteiro, L. R (2011). Passagem de Imagens, Imagens da Passagem. Buala: Cultura contemporânea africana. Retrieved June 02, 2015, from http://www. buala.org/pt/afroscreen/passagem-de-imagens-imagens-da-passagem.

Morton, D. (2010). Revolutionary force meets immovable object. Hotel Universo. Retrieved June 02,2015, http:/ / hoteluniverso.wordpress.com/2010/11/29/ revolutionary-force-meets-immovable-object/.

Muiuane, A. P. (2006). Datas e documentos da bistória da FRELIMO: De 1960 a 1975, ano da independência de Moçambique (3rd ed.). Maputo: CIEDIMA, SARL.

Newitt, M. (1995). History of Mozambique. Bloomington: Indiana University Press.

Nichols, B. (2010). Introduction to documentary (2nd ed.). Bloomington: Indiana University Press.

Pasley, V. (2009). Kuxa Kanema. Third cinema and its transatlantic crossings. In F. Ekotto (Ed.), Rethinking third cinema. The role of anti-colonial media and aesthetics in postmodernity (pp. 107-123). Münster: Lit.

Piçarra, M. C. (2011). Salazar vai ao Cinema II: A Politica do Espirito no Jornal Português. Lisboa: DrellaDesign.

Pinto, A. C. (2001). O fim do Império Portugués. A Cena internacional, a Guerra colonial, e a Descolonização 1961-1975. Lisboa: Livros Horizonte.

Pitcher, M. A. (2006). Forgetting from above and memory from below: Strategies of legitimation and struggle in postsocialist Mozambique. Africa: Journal of the International African Institute, 76(1), 88-112.

Ribeiro, M. C. (2004). África no feminino: As Mulheres portuguesas e a Guerra colonial. Revista Crítica de Ciências Sociais, 27(68), 7-29.
Roof, M. (2004). African and Latin American cinemas. Contexts and contacts. In F. Pfaff (Ed.), Focus on African films (pp. 241-270). Bloomington: Indiana University Press.

Rosenstone, R. A. (2001). The historical film: Looking at the past in a postliterate age. In M. Landy (Ed.), The historical film. History and memory in media (pp. 50-66). New Brunswick: Rutgers University Press.

Schefer, R. (2011). O Nascimento de uma Imagem. Mueda, Memória e Massacre, de Ruy Guerra (1979). Buala: Cultura contemporânea africana. Retrieved June 02,2015,http://www.buala.org/pt/afroscreen/passagem-de-imagens-imagensda-passagem.

Seibert, G. (2003). The vagaries of violence and power in post-colonia Mozambique. In J. Abbink \& M. de Bruijn (Eds.), Rethinking resistance (pp. 253-276). Brill: Leiden.

Sousa, J. (2008). Eduardo Mondlane e a Luta pela Independência de Mocambique. In L. R. Torgal, F. Tavares Pimenta, \& J. Soares Sousa (Eds.), Comunidades imaginadas: Nafãa e Nacionalismos em África (pp. 149-160). Coimbra: Imprensa da Universidade de Coimbra.

Taylor, C. (1983). Film reborn in Mozambique. Junnpcut, 28, 30-31.

Thackway, M. (2003). Africa shoots back: Alternative perspectives in sub-Sabaran francopbone African film. Bloomington: Indiana University Press.

Ukadike, N. F. (2004). The other voices of documentary: Allah Tantou and Afrique, je te plumerai. In F. Pfaff (Ed.), Focus on African films (pp. 159-172). Bloomington: Indiana University Press.

Vaz, N. (1997). Opiniōes públicas durante as Guerras de Africa, 1961-1974. Lisboa: Quetzal.

Wheeler, D. L. (1980). Joaquim Mouzinho de Albuquerque (1855-1902) e a Política do Colonialismo. Análise Social, XVI(61-62), 295-318.

Wolf, E. (1982). Europe and the people without history. Berkeley: University of California Press.

Zryd, M. (2003). Found footage film as discursive metahistory. Craig Baldwin's tribulation 99. The Moving Image, 3(2), 40-61. 